\title{
Chapter 6 \\ Building Resilience: Using BRiTE \\ with Beginning Teachers in the United \\ States
}

Lynn Sikma

\begin{abstract}
The most recent data available on beginning teacher attrition in the United States estimates that $17.3 \%$ of teachers leave the profession within their first five years teaching. Most efforts to improve this focus on implementing mentoring and induction programs. However, improving beginning teachers' resilience may be an additional strategy, as it develops individual protective factors independent of working conditions. This chapter describes a series of professional development workshops, rooted in the BRiTE modules, presented to two groups of beginning teachers in the southeastern United States during the 2017-2018 school year. All teacher participants were K-12 teachers in their first three years teaching, most teaching in a rural setting. Strategies that have been successfully implemented will be shared along with participant feedback that demonstrates value of the modules for supporting beginning teachers.
\end{abstract}

Keywords Beginning teachers · Professional development · Induction

\subsection{Introduction}

Teaching is a complex work, as it is both intellectual and emotional in nature. Teachers need to thoroughly understand the content they teach and how to teach it, but also how to cope when they feel inadequate or under-supported. In the United States, the focus of most teacher preparation programs is on the intellectual aspect of the job, with little explicit focus on the socio-emotional coping strategies necessary to succeed. Thus, teachers enter the profession with the capacity to teach effective lessons, but not necessarily with the tools to help them cope with the emotional stressors of the work. This can lead to negative outcomes, like attrition, early in their career. This chapter discusses the features of a university-led professional development series rooted in the BRiTE modules implemented in the southeastern United States with beginning teachers. The program was chosen because of its socio-emotional focus,

L. Sikma $(\bowtie)$

UNCW Watson College of Education, Wilmington, NC, USA

e-mail: sikmal@uncw.edu 
with the belief that, although designed for pre-service teachers in Australia, the key underpinnings of the program would make it equally relevant for beginning teachers in the United States. In addition to a description of the professional development program, the chapter also discusses participants' feedback about the relevancy of the program and suggestions for others who want to use it in a similar context.

\subsection{Teaching in the United States}

In the United States there are three main levels of school. Elementary school (grades PK-5) houses the early years of school for students. Children under the age of five attend pre-school or pre-kindergarten (PK) in a private or public school. Children usually enter public schools via kindergarten at age 5 or 6 and complete fifth grade at age 11 . During the elementary school years, students generally have one main teacher for all core subject areas (English Language Arts, Mathematics, Science, and Social Studies), though some schools may have teachers specialize in an area. Middle school houses grades 6-8 with students aged 11-14. During middle school, students begin rotating teachers, with each teacher generally specializing in one or two core subject areas. Students usually have elective courses (e.g., technology, foreign language); they can choose as part of their coursework and can also choose to engage in extracurricular activities (e.g., basketball, orchestra) during this phase of schooling. High school, which houses grades 9-12, is the last phase of public schooling prior to entering university. During high school, students have different teachers for each subject area and have some level of flexibility in their coursework choices. Students are required to take certain core coursework (e.g., two years of a laboratory science) but may choose to take additional, more advanced coursework in areas of their choosing (e.g., four years of a laboratory science).

Teachers have different experiences across those levels. For example, at the elementary level, a teacher is expected to have a broad knowledge base, as they are required to prepare daily lessons in four core subject areas, each meeting the needs of all students in the classroom. At the high school level, teachers specialize in one subject area (e.g., science) and are expected to have a depth of knowledge in their content area. They may teach different sections of the same course several times throughout the day, they may teach completely different levels of the same subject (e.g., general biology and advanced biology), or they may teach different content courses under the umbrella of their specialty (e.g., chemistry and physics). At the elementary level, teachers are generally required to do extra duties like help unload/load buses at the beginning/end of the day or supervise students during lunch or recess. At the high school level, teachers may not have this duty, but they may be asked to coach a sport, run a club, or some other type of extracurricular activity. Middle school teachers may be asked to do lunch duty and coach a sport. Ultimately, teaching at any level comes with its own unique set of challenges in addition to the universal challenges faced by teachers (e.g., testing pressures) (von der Embse et al. 2016). 
In the United States, the teaching profession has a national attrition rate of $8 \%$, and less of a third of those leaving the profession are doing so due to retirement (CarverThomas and Darling-Hammond 2017; Goldring et al. 2014). The rate of attrition for new teachers is the highest, with between approximately a third and a half of teachers either leaving the profession or their school within the first five years (Alliance for Excellent Education 2005; Curren and Goldrick 2002; Darling-Hammond 2003; DeAngelis and Presley 2011; Herbert and Ramsay 2004; Ingersoll 2012; Ingersoll and Kralik 2004; Smith and Ingersoll 2004). The most current reported attrition rate for beginning teachers in the United States is $17.3 \%$, with $80 \%$ of those leaving voluntarily (Gray and Taie 2015). In addition to this, $10 \%$ of new teachers move schools, $60 \%$ voluntarily, resulting in an overall turnover rate of $27 \%$ (Gray and Taie 2015).

The most cited reason for teacher departure is testing and accountability pressures, followed by a lack of administrative support, dissatisfaction with working conditions, and dissatisfaction with the teaching career (Carver-Thomas and Darling-Hammond 2017). Salary has been found to be a key contributor to attrition (Darling-Hammond 2010; Gonzales et al. 2008; Hanushek et al. 2004; Kang and Berliner 2012).

North Carolina is geographically located in the southeastern region of the United States. The geography of the state creates large expanses somewhat removed from others, resulting in a large amount of rural areas in the state. Teacher attrition trends in North Carolina follow those of the United States, with similar rates and rationale (Department of Public Instruction 2019). Rural schools have higher turnover rates than non-rural schools; 25 of the 30 districts ranked highest in turnover are rural districts (Public Schools First 2019).

Another key variable that seems to impact teacher turnover is teacher preparation. Teachers who have gone through alternative certification (which does not require methods coursework or student teaching), called lateral entry teachers, are two to three times more likely to leave the profession than their formally prepared peers (Ingersoll and Merrill 2012). These teachers enter the profession with a bachelor's degree in the area in which they teach, but little to no formal education training. Lateral entry teachers obtain their teaching certification(s) after they begin their jobs, between years 1 and 3. Formal programs like Teach for America are highly structured and designed to recruit recent college graduates to teach hard-to-staff schools (usually urban settings) for two years while providing intensive workshops and training prior to and while teaching. Other alternative pathways are less formalized, but still require teachers to attend training in the form of workshops or university coursework (Mayer et al. 2003).

In North Carolina, due to high teacher turnover and hard to staff areas, there has been a recent increase in lateral entry teachers. There was a $21.4 \%$ increase in lateral entry teachers in the state from the 2016-2017 to 2017-2018. There has been a general trend upward in the number of lateral entry teachers employed by the state in recent years, reflecting both a shortage of qualified teaching candidates in the state and an increased need to better understand the needs of this subgroup of teachers. During 2017-2018, 15.1\% of employed lateral entry teachers quit compared to $7.62 \%$ 
of non-lateral entry teachers, giving them a $104 \%$ higher rate of attrition than their non-lateral entry counterparts (DPI 2019).

One way attrition has been addressed in the United States is through the implementation of induction and mentoring programs. Though participation in intensive induction and mentoring programs has been found to have a positive correlation with retention (Andrews and Quinn 2005; Gray and Taie 2015; Ingersoll and Strong 2011; Smith and Ingersoll 2004), so has improving teachers' resilience (Bowles and Arnup 2016; Tait 2008). Often, there is little that can be done to change the working conditions (e.g., salary), but teachers' responses to those conditions can be addressed through building resilience.

\subsection{Why BRiTE?}

Teacher education programs in the United States focus on preparing teacher candidates for classroom-based instructional practice. This includes coursework on child development (developmental psychology), content, and methods/field courses covering assessment, planning, instructional, and student engagement strategies (Council for the Accreditation of Educator Preparation 2019). Generally missing from these programs is work pertaining to the social, emotional, and motivational needs of teachers once they enter the field. Researchers have argued that teachers' capacity to deal with the challenges related to these areas requires resilience, which is particularly important for novice teachers (Gu and Day 2013; Johnson et al. 2014; Peters and LeCornu 2007; Tait 2005). According to Gu and Day (2013), "To teach, and to teach at one's best over time, has always required resilience" (p. 22).

Differing definitions of teacher resilience exist throughout the literature, with some agreement that it is a complex, dynamic process consisting of the interplay of personal and contextual factors that allows teachers to bounce back (or forward) from stressors and adversity (Beltman et al. 2011; Benard 2004; Gu and Day 2007, 2013; Mansfield et al. 2012; Tait 2008). Resilience is not something innate, but rather, something that can be developed (Bobek 2002; Howard and Johnson 2014; Johnson et al. 2014; Tait 2008). Resilience can help with feelings of stress and burnout (Howard and Johnson 2004; Richards et al. 2016), help teachers sustain commitment and overall job satisfaction (Brunetti 2006), and improving resilience may lead to better teacher retention (Bobek 2002; Doney 2013; Gu and Day 2007; Peters and LeCornu 2007; Tait 2008). Given the benefits to individual teachers and the profession, teacher educators need to consider ways to improve resilience in pre-service and in-service teachers.

The Building Resilience in Teacher Education, or BRiTE, program (Mansfield et al. 2016) (see Chap. 3) is a practical way to address resilience with teachers. Similar programs do not currently exist in the United States and conditions in the southeastern region of North Carolina (e.g., rural, poverty, high beginning teacher turnover) suggest teachers could benefit from explicit experiences related to building resilience. This chapter outlines the use of the online modules as part of a hybrid 
professional development series implemented with beginning teachers (career years 1-3) in southeastern North Carolina. Though developed to build resilience in preservice teachers in Australia, the content and skills addressed seem to be equally applicable to both pre-service and in-service teachers in the United States. In implementing the program, I wanted to see if and how it was, in fact, applicable to in-service, beginning teachers in a U.S. context.

\subsection{Context and Participants}

Two cohorts of teachers participated in a series of BRiTE-focused professional development during the 2017-2018 school year. The professional development started in November and occurred monthly. I designed and facilitated each session and the college's assistant PDS director joined me at each session. Both cohorts were instructed to complete the BRiTE online modules (www.brite.edu.au), attend a series of five workshops inspired by the information within the modules, and complete an exit survey at the end of the program. One was a large group of K-12 teachers in a rural county approximately 50 miles from the university. The other group was a small group of K-12 teachers from across the southeastern region of the state that were selected as award recipients based on their leadership and innovation in the classroom. Additional information about implementation specificities for each group is found below.

\subsubsection{Group One: Franklin County}

Franklin County is located in southeastern North Carolina approximately 50 miles from the university. During the 2017-2018 school year, it served 5,598 students in grades PK-12. The public school district comprised six elementary schools (PK-5), five middle schools (6-8), three high schools (9-12), and one cooperative innovative high school split between two campus sites. It employs roughly 560 teachers across these schools and during the 2017-2018 school year, 67 new teachers (teachers in career years 1-3) participated in the district's Beginning Teacher Support Program (BTSP). The breakdown of the new teachers can be found in Table 6.1.

Franklin County's Beginning Teacher Support Program (BTSP) is a three-year program mandated for all teachers who have taught for less than three years. This includes two groups of teachers. Beginning teachers (BTs) are fully licensed because they have completed a formal approved teacher preparation program and have obtained at least a minimum score on state-mandated content-based exams in their main teaching field. Lateral entry, or provisionally licensed teachers (LEs), hold a lateral license to teach because they have not completed a formal teacher training program or passed the state-mandated content-based examinations but hold a bachelor's degree in the area they are assigned to teach. A facet of the BTSP is to help LE 
Table 6.1 Franklin County new teachers, 2017-2018 school year

\begin{tabular}{l|l|l|l|l}
\hline $\begin{array}{l}\text { Type of teacher/Years of } \\
\text { experience }\end{array}$ & Elementary $(\mathrm{K}-5)$ & Middle (6-8) & High (9-12) & Total \\
\hline BT1 & 3 & 4 & 1 & $\mathbf{8}$ \\
\hline BT2 & 5 & 1 & 3 & $\mathbf{9}$ \\
\hline BT3 & 5 & 3 & 3 & $\mathbf{1 1}$ \\
\hline LE1 & 3 & 8 & 6 & $\mathbf{1 7}$ \\
\hline LE2 & 7 & 2 & 3 & $\mathbf{1 2}$ \\
\hline LE3 & 1 & 2 & 7 & $\mathbf{1 0}$ \\
\hline Total & $\mathbf{2 4}$ & $\mathbf{2 0}$ & $\mathbf{2 3}$ & $\mathbf{6 7}$ \\
\hline
\end{tabular}

$B T$ Beginning teacher (formal teacher preparation program), $L E$ lateral entry (no teacher preparation program; degree in area assigned to teach)

teachers gain full licensure by the end of their third year by supporting them through required coursework and testing.

The BTSP provides new teachers with support from the district's beginning teacher coordinator, mentors, lead teachers, principals, assistant principals, and central office staff with the goal of growing and retaining effective instructional leaders. The program begins with a new teacher orientation before the start of the school year that covers district and state expectations and resources. All new teachers are formally assigned a trained mentor, with attempts made to match the subject area/grade level of the new teachers as much as possible. Throughout the year, mentor/mentee pairs complete and submit logs and documentation of their one-hour weekly meetings on assigned topics. New teachers in the BTSP also are required to attend professional development meetings throughout the year. These include school-based professional learning community (PLC) meetings and formal district level professional development workshops. Because of their strong partnership with the university, Franklin County often reaches out for university run, yearlong professional development series.

Prior to the 2017-2018 school year, the beginning teacher coordinator reached out and requested a professional development series from the university's professional development system's (PDS) office. Several of her beginning teachers had attended a series of sessions I presented on social networking and relationship building during two on-campus professional learning days the year before and expressed to her how beneficial they found it. She asked the PDS office if I could do a longer series as part of the year's BTSP. When I spoke to her about what she was looking for, she explained that she had a very high needs district; most students in the district faced some level of poverty, test performance levels were low, and the rural (and thus, far removed) nature of the district coupled with low salaries made it hard to recruit and retain teachers. Because of this, she had an inordinately high amount of lateral entry teachers and they were experiencing difficulty coping with and adjusting to the work of teaching beyond just instruction. She wanted professional development that would address this aspect of the job, in hopes that it would help with retention 
and motivation. I spoke to her about the BRiTE program and offered to develop workshops that would align to the content of the online modules and would include the social networking sessions that she originally requested. After reviewing the program, she agreed it would be a good fit for the needs of her beginning teachers.

The 67 new teachers in Franklin County attended a series of five workshops derived from the BRiTE modules over the course of the school year and each teacher successfully completed all of the online modules, as they were required to submit their certification of completion to the beginning teacher coordinator at the end of the last workshop. Though teachers were required to attend the workshops, several teachers managed or coached extracurricular activities that occurred at the same time as the workshops, so although every teacher attended some of the workshops, not every teacher attended all of the workshops.

At the end of each workshop, the teachers were asked to complete an anonymous session exit survey (required by the PDS office for any school-based professional development sessions). The survey asked them to rate the session in various categories (e.g., relevancy of content, engagement level, clarity, presenter, length of session) from 1 to 5 and to answer two open-ended short answer questions at the end (What was the best part of today's session? What part of today's session would you change?). At the end of the program in May, the beginning teacher coordinator sent the teachers a link to a longer online evaluative survey to complete. Unlike the modules, she did not set a requirement for completion of the survey. This survey included questions about both the BRiTE modules and the workshop experiences. Questions included Likert scale questions and open-ended short answer questions.

\subsubsection{Group Two: Promise of Leadership Award Recipients}

The Promise of Leadership (POL) Award is a two-year program hosted by the university's PDS office honoring exemplary beginning teachers that work within the university's PDS. In the fall of each school year, the office sends out an invitation to participate to all PDS schools. Beginning teachers $(\mathrm{PK}-12)$ in their second career year are nominated by their school system for the award due to their display of leadership and innovation in the classroom. A panel comprised faculty and staff at the university reviews nominations and ten teachers are selected as award recipients. In addition to gaining recognition, award recipients participate in university-led professional development, work with a faculty member and designated Master Teacher ${ }^{1}$ on a project of their choosing, and present a related professional development session to other beginning teachers at an end of the year event hosted by the PDS office.

\footnotetext{
${ }^{1}$ This three-year program is hosted by the university's PDS office and recognizes ten veteran teachers for their leadership in the field. During the program, Master Teachers are paired with a university faculty mentor who collaborates with them on one or more mutually beneficial professional growth opportunities.
} 
Table 6.2 Promise of leadership participants, 2017-2018

\begin{tabular}{l|l|l|l|l}
\hline $\begin{array}{l}\text { Type of teacher/Years of } \\
\text { experience }\end{array}$ & Elementary (K-5) & Middle (6-8) & High (9-12) & Total \\
\hline BT2 & 3 & 3 & 3 & $\mathbf{9}$ \\
\hline LE2 & 0 & 0 & 1 & $\mathbf{1}$ \\
\hline Total & $\mathbf{3}$ & $\mathbf{3}$ & $\mathbf{4}$ & $\mathbf{1 0}$ \\
\hline
\end{tabular}

The 2017-2018 cohort included three elementary teachers, three middle school teachers, and four high school teachers (see Table 6.2). Five of the ten teachers taught in rural counties and five taught in the district adjacent to the university. Only one of the high school POLs was a lateral entry teacher, the rest were BTs in year two. The assistant PDS director recruited me to lead the professional development for these teachers during the program. She was in charge of the program and had planned a book study for them on growth mindset. She felt that the series I was developing for Franklin County would be useful for these teachers since they were facing similar challenges in their districts and that it would align well with the book study. Like the Franklin County teachers, the POLs attended five workshops derived from the BRiTE modules, and nine of the ten teachers attended all five sessions. The teachers were asked to complete the BRiTE modules prior to each workshop, though only a few completed or somewhat consistently ( 3 or more) completed the modules. Teachers were not held accountable for the completion of the modules the way the Franklin County teachers were (by district personnel), which may have contributed to their inconsistent completion.

The POLs were given the same end of program evaluation survey as the Franklin County teachers, and the assistant PDS director sent it out to the teachers in May. In addition to this survey, the POLs were also asked to complete a college-generated survey about the POL program. This survey included rating scale questions about their experience and open-ended short answer questions.

\subsection{The Workshops}

Each workshop was designed to complement one of the BRiTE modules and was delivered identically to both the Franklin County and POL groups. With the exception of the opening workshop session, participants were asked to complete the modules prior to each workshop, since content from the modules was discussed during each meeting. The workshops lasted about an hour-and-a-half each and Table 6.3 aligns the BRiTE topic with each workshop's topic. There were two workshops relating to the Relationships BRiTE module and the workshop on Managing Stress and Wellbeing covered information found in both the Wellbeing and Emotions modules.

In designing the workshops, I began with the two existing workshops I had already developed on social networking and relationships, since those were specifically 
Table 6.3 BRiTE modules and corresponding workshop titles

\begin{tabular}{l|l}
\hline BRiTE module & Workshop title \\
\hline Building Resilience & Introduction to Teacher Resilience \\
\hline Relationships & Making Connections: Using Your Social Network to Your Advantage \\
\hline Relationships & Developing and Strengthening Your Support Network \\
\hline Taking Initiative & Taking Initiative \\
\hline $\begin{array}{l}\text { Wellbeing } \\
\text { Emotions }\end{array}$ & Managing Stress and Wellbeing \\
\hline
\end{tabular}

requested by Franklin County. These workshops focused on mapping out participants' egocentric social support networks, examining the networks, and discussing ways to expand their networks. The content of these workshops aligned well with the Relationships module, so I modified the workshops to purposefully include information regarding building and maintaining relationships found within the BRiTE modules so the content would align seamlessly. I approached the Managing Stress and Wellbeing workshop similarly; I had an existing workshop on mindfulness that I had been developing that I modified to better align with the BRiTE modules on Emotions and Wellbeing. For example, I added several discussion prompts relating to managing stress and mental health, two topics directly derived from the Wellbeing module. Since the content of these modules complemented one another, I felt I could combine these into one workshop since I only had five sessions and had already committed to doing two sessions on Relationships. The other two workshops were derived directly from module content; they followed the same basic structure (e.g., the Taking Initiative workshop focused on problem-solving, professional development, and communication) and utilized some content from the modules. Additional content was added to enhance these workshops so they were not just mere presentations about the modules (e.g., student resilience was discussed in the first workshop, boundary setting was added to the Taking Initiative workshop).

Each workshop provided participants with information related to the topic, opportunities to reflect on their own experiences and the module content, and an activity/discussion related to the topic. At the end of each workshop, the participants had homework; this included completing the next module and some sort of reflection/action based on the content from the workshop. Table 6.4 provides an overview of the information covered, the activity/discussion topic, and the participants' homework (in addition to completing the module).

\subsection{Feedback}

At the completion of the workshops in May 2018, each participant was asked to complete an online end of program evaluative survey about their opinions of the modules and the workshops. Though the workshops were directly aligned to the 
Table 6.4 Workshop overview

\begin{tabular}{|c|c|c|c|}
\hline Workshop & Information covered & Activity/Discussion & Homework \\
\hline $\begin{array}{l}\text { Introduction to } \\
\text { Teacher Resilience }\end{array}$ & $\begin{array}{l}\text { - What is resilience? } \\
\text { - What impacts } \\
\text { resilience? } \\
\text { - Teacher resilience } \\
\text { - Resources }\end{array}$ & $\begin{array}{l}\text { Reflection: What does } \\
\text { resilience look like in } \\
\text { your life? } \\
\text { Activity: Introduction } \\
\text { to BRiTE modules }\end{array}$ & $\begin{array}{l}\text { Reflect on moments of } \\
\text { resilience }\end{array}$ \\
\hline $\begin{array}{l}\text { Making Connections: } \\
\text { Using Your Social } \\
\text { Network to Your } \\
\text { Advantage }\end{array}$ & $\begin{array}{l}\text { - What is a social } \\
\text { network } \\
\text { - What do social } \\
\text { network maps look } \\
\text { like } \\
\text { - What do social } \\
\text { network maps tell } \\
\text { us? }\end{array}$ & $\begin{array}{l}\text { Reflection: Who is in } \\
\text { your support network? } \\
\text { Activity: Draw out } \\
\text { your support network } \\
\text { Discussion: Patterns of } \\
\text { networks }\end{array}$ & $\begin{array}{l}\text { Consider your } \\
\text { network in action and } \\
\text { what you have to offer } \\
\text { others }\end{array}$ \\
\hline $\begin{array}{l}\text { Developing and } \\
\text { Strengthening Your } \\
\text { Support Network }\end{array}$ & $\begin{array}{l}\text { - Types of support } \\
\text { sought by new } \\
\text { teachers } \\
\text { - Building } \\
\text { relationships with } \\
\text { colleagues, parents, } \\
\text { and students } \\
\text { - How to expand your } \\
\text { network and be a } \\
\text { strategic extrovert } \\
\text { - Maintaining } \\
\text { relationships }\end{array}$ & $\begin{array}{l}\text { Activity: Map analysis } \\
\text { Reflection and } \\
\text { Discussion: What are } \\
\text { your needs as they } \\
\text { compare to what other } \\
\text { new teachers need? } \\
\text { What are you an } \\
\text { expert at? }\end{array}$ & $\begin{array}{l}\text { Make an additional } \\
\text { network connection }\end{array}$ \\
\hline Taking Initiative & $\begin{array}{l}\text { - Problem-solving } \\
\text { - Professional } \\
\text { development } \\
\text { - Communicating } \\
\text { effectively and } \\
\text { assertively } \\
\text { - Setting boundaries }\end{array}$ & $\begin{array}{l}\text { Activity/Discussion: } \\
\text { School-based } \\
\text { scenarios }\end{array}$ & $\begin{array}{l}\text { Say no to something } \\
\text { (set a boundary) }\end{array}$ \\
\hline $\begin{array}{l}\text { Managing Stress and } \\
\text { Wellbeing }\end{array}$ & $\begin{array}{l}\text { - Stress and mental } \\
\text { health } \\
\text { - Maintaining } \\
\text { wellbeing } \\
\text { - Dealing with stress } \\
\text { - Mindfulness } \\
\text { - Summation of } \\
\text { workshop series }\end{array}$ & $\begin{array}{l}\text { Discussion: How do } \\
\text { you manage stress? } \\
\text { Activity: mindfulness } \\
\text { activities (e.g., } \\
\text { breathing exercises, } \\
\text { focus/teambuilding, } \\
\text { slow eating) }\end{array}$ & $\begin{array}{l}\text { Apply what you've } \\
\text { learned through this } \\
\text { program }\end{array}$ \\
\hline
\end{tabular}

module content, I wanted to see (a) if the teachers' experiences differed between the two modalities and (b) how relevant they found the modules and the workshops. Franklin County teachers were also asked to complete individual workshop evaluations after each meeting that included rating scale questions and two short answer questions. The Promise of Leadership Award recipients were asked to complete an 
additional program exit survey from the college, sent out at the same time as the evaluative survey, and half responded.

There was a low response rate $(22 \%)$ with the end of program evaluation survey, most likely due to the timing of dispersal aligning with the end of the school year. The initial email with the survey link was sent out the week before state testing began and only one teacher completed it. A reminder email was sent out after testing ended, but this corresponded with the last week of school. A third email was sent out a few weeks after school ended. Of the 17 responses, 15 were from Franklin County teachers and a third of them were incomplete. The low response rate from the POLs on this survey could be due to their requirement to complete two surveys, which were sent out from the PDS office together. These teachers may have thought if they completed one, they need not complete the other. If I were to implement this again, I would try to embed it as part of the final workshop to improve the response rate.

\subsubsection{Relevance of Program}

Though the response rate to the end of program survey was low, there were trends across the surveys. There was not a marked difference in responses between lateral entry and beginning teachers. Given that the lateral entry teachers lacked any formal teacher training, it was expected that these teachers would find the modules and workshops to be more helpful than their beginning teacher counterparts, but this was not the case, as both groups had similar responses.

Overall, the teachers had a positive (ratings 8-10) to somewhat positive (ratings 57) response regarding the BRiTE modules. Teachers found the content of the modules interesting and relevant and all reported feeling that the content of the modules was appropriate for beginning teachers. All respondents somewhat or strongly agreed that the modules promoted resilience. Only one respondent felt negatively toward the modules, which she suggested was because she had 11 years of experience prior to hire in the district and didn't feel like a new teacher. Critiques of the modules mentioned included feeling that the modules took too long to complete (2) and that they should include U.S. experiences (1). The module most teachers identified as being the most useful to them was the module on Wellbeing.

All of the teachers who completed the end of program survey reported a positive response regarding the workshops. They felt strongly that the content was relevant, organized, and appropriate for beginning teachers. All respondents somewhat or strongly agreed that the workshops have helped increase their awareness and understanding of their own resilience and helped them feel more confident as a teacher. The only critiques of the workshops were related to timing, not content. The workshops occurred at the end of the school day, and this is something the Franklin County teachers mentioned consistently throughout the series in their end-of-workshop evaluations. The workshops the teachers found most useful were the workshops related to relationships/social networks and managing wellbeing and stress. This was not 
surprising, as these sessions were particularly activity-heavy and hands on. These sessions also aligned to the participants' preferred online modules.

Within the survey, there was an open-ended question asking participants if they had anything they wanted to add about their experience. Since only a few chose to respond, all of their quotes are found below:

- I thought all the workshops were useful in more ways than one. It allowed for so much collaboration that I normally would not have and to make connections with other teachers across the area-that was awesome! (BT3)

- Thought they were very helpful for BT teachers. I thought they applied to how I felt and what I was experiencing as a teacher (BT2).

- Great information and activities for sharing experiences (LE3).

- As a result of this workshop, I have been working harder to strengthen relationships (LE2).

- I thought everything we covered was informative and helpful. It helped to know that other teachers were feeling the same way as me (BT2).

- I learned how to maintain a better work-life balance (LE1).

Overall, the teachers who completed the end of program survey felt the modules and workshops were relevant for both their context and level of experience and it seemed like the workshops were important to enhance the module content.

\subsubsection{Community Building}

Typically, new teachers in southeastern North Carolina receive professional development related to instructional practices as part of their induction experience (e.g., differentiation, digital literacy, visual learning strategies). These workshops were atypical because they focused more on socio-emotional topics and on the teachers as individuals. Throughout the year, participants consistently described the meetings as "refreshing" and a source of much needed community. This was particularly true for the smaller group of POLs. They formed a tight bond relatively quickly, in part because they were discussing very personal topics beginning in the first meeting. Since they were such a small group, everyone was inherently forced to share their thoughts, often about vulnerable topics. For example, the first workshop opened with a discussion about what resilience looks like in their students. After a few people shared stories about their students, one of the middle school teachers got very emotional as he described one of his students who was undergoing cancer treatment for the third time. He shared how inspired he was every day by this student, who, despite having a huge obstacle to overcome, maintained the most positive outlook on life. At the end of the second meeting, one teacher remarked, "I love coming to these meetings because they feel like therapy. They are so focused on $m e$, as in the person, not just the teacher." They felt heard, as the message I consciously expressed during every workshop was one of empathy and support. One POL noted in her exit survey from the college, "It felt like a community very quickly, and I was always just 
excited to get together to talk about problems and successes." Another noted, "Part of the reason this program worked so well is because you can tell you genuinely care about us as people and teachers, and I really appreciated that."

Another facet of the workshop series the teachers appreciated was the ability to network with other new teachers. In their post-workshop evaluations, the Franklin County teachers would consistently mention "talking to and hearing from other new teachers in the district" as one of the most beneficial aspects of the workshop, regardless of topic. When asked to share a piece of the POL program that had the strongest impact on them as a beginning teacher, every teacher mentioned networking with other beginning teachers. One teacher shared, "I loved every part of this experience, the most impactful was the meetings with other POLs and having meaningful discussions with the group." This is consistent with the induction literature related to the relational needs of new teachers; the workshops provided a catalyst for relationships to form between the new teachers (Ingersoll and Strong 2011; Ronfeldt and McQueen 2017; Smith and Ingersoll 2004).

Part of the success of this professional development series was due to the fact that the participants considered the presenters to be outsiders. That is, each meeting was a safe space independent of anyone who was in an evaluative or administrative position over the teachers. In Franklin County, during a session in which the mentor/mentee relationship was going to be discussed, the beginning teacher coordinator suggested that mentors be invited to partake in the session. This offer was declined as it was important that the new teachers felt comfortable sharing any struggle they might be facing in that relationship. One POL expressed in the exit survey, "We had the freedom to discuss issues and receive feedback from those who were not directly involved in the situation." This safety allowed the teachers to discuss delicate topics like struggles with colleagues or administrators.

It was evident in their exit surveys that the POL group embraced and applied the resilience material. One teacher noted, "The teacher resilience [material] has helped me be mindful when I am having trying times." Several mentioned sharing the material and information with other teachers at their schools. One said, "I try everyday to at least get one person to try something we tried during the sessions." Another said, "I always keep in mind the resiliency training and try to help out other stressed out teachers."

\subsection{Conclusion}

In the United States, teacher preparation programs are primarily focused on preparing teachers for instructional practice, often ignoring or overlooking preparation related to the socio-emotional aspects of teaching (Council for the Accreditation of Educator Preparation 2019). As a result, many teachers enter the profession and feel overwhelmed and underprepared for the demands of the job and end up leaving early in their careers (Alliance for Excellent Education 2005; Gray and Taie 2015; Smith and 
Ingersoll 2004). The BRiTE program addresses this lack of preparation by providing teachers with the tools needed to deal with difficult situations.

Though no generalizable conclusions can be made from this one example, the new teachers involved in the professional development recognized the impact the program made on their own resilience, particularly relating to work-life balance and relationships. Although the end of program survey response rate was low, this message was reflected consistently in the feedback following each workshop. An unexpected outcome was the development of a strong professional learning community that developed with the smaller POL group as a result of the reflections, discussions, and activities derived from the BRiTE materials. This PLC formation may further contribute to the teachers' resilience (Waddel 2007). A year following implementation, the group is still actively engaged in regular discussions about their classroom practice and contexts and some of them are providing professional development to other new teachers in their schools regarding what they learned in the program.

The following suggestions are offered for those interested in implementing a similar program in a U.S. context:

- Provide teachers with a document explaining how each module aligns to the state professional teaching standards prior to completion. Despite explanation that the program was aligned to the Australian professional teaching standards but that these standards were very similar to the U.S. state teaching standards, teachers were critical of the fact that it was an Australian program.

- Similarly, despite prompting at the beginning of the series to ignore them, some teachers (particularly those in career year 3 ) were offended by the use of the preservice label throughout the modules. Therefore, it is of particular importance to deliberately align examples to the in-service experience.

- Though the online modules could certainly be used a standalone experience, part of the strength of this professional development experience seemed to be the hybrid nature of implementation. Providing teachers time to complete the modules before the face-to-face meetings allowed more time for activities, reflections, and discussion at a deeper level.

- If possible, implement with a small group. Though the Franklin County teachers reported satisfaction with their experiences, the group of 67 people did not form the same tight-knit community and PLC as the 10-person POL group.

Overall, this was a successful professional development series and one that is now regularly requested by school partners. Though the BRiTE online modules were developed for and are used with teachers in an Australian context, the content and skills addressed as part of the program are equally applicable to a U.S. context (and perhaps other international contexts, as well) (see Chaps. 8 and 9). It could certainly fit into teacher education programs, but it could also be part of the induction experience for new teachers, similar to the program implementation described here. 


\section{References}

Alliance for Excellent Education. (2005). Teacher attrition: A costly loss to the nation and to the states. Washington, DC: Author.

Andrews, B. D., \& Quinn, R. (2005). The effects of mentoring on first-year teachers' perceptions of support received. The Clearing House, 78(3), 110-116.

Beltman, S., Mansfield, C., \& Price, A. (2011). Thriving not just surviving: A review of research on teacher resilience. Educational Research Review, 6(3), 185-207. https://doi.org/10.1016/j.edu rev.2011.09.001.

Benard, B. (2004). Resiliency: What have we learned? San Francisco: WestEd.

Bobek, B. L. (2002). Teacher resiliency: A key to career longevity. The Clearing House, 75(4), 314-323.

Bowles, T., \& Arnup, J. (2016). Should I stay or should I go? Resilience as a protective factor for teachers' intention to leave the teaching profession. Australian Journal of Education, 60(3), 229-244. https://doi.org/10.1177/0004944116667620.

Brunetti, G. J. (2006). Resilience under fire: Perspectives on the work of experienced, inner city high school teachers in the United States. Teaching and Teacher Education, 22(7), 812-825. https:// doi.org/10.1016/j.tate.2006.04.027.

Carver-Thomas, D., \& Darling-Hammond, L. (2017). Teacher turnover: Why it matters and what we can do about it. Palo Alto, CA: Learning Policy Institute.

Council for the Accreditation of Educator Preparation. (2019). 2013 CAEP Standards. http://cae pnet.org/ /media/Files/caep/standards/caep-standards-one-pager-0219.pdf?la=en.

Darling-Hammond, L. (2003). Keeping good teachers: Why it matters, what leaders can do. Educational Leadership, 60(8), 6-13.

Darling-Hammond, L. (2010). Recruiting and retaining teachers: Turning around the race to the bottom in high-needs schools. Journal of Curriculum and Instruction, 4(1), 16-32. https://doi. org/10.3776/joci.2010.v4n1p16-32.

DeAngelis, K., \& Presley, J. (2011). Toward a more nuanced understanding of teacher attrition. Education and Urban Society, 43(5), 598-626. https://doi.org/10.1177/0013124510380724.

Department of Public Instruction. (2019). 2017-18 Report to the North Carolina General Assembly: State of the teaching profession in North Carolina. Raleigh, NC: Author.

Doney, P. A. (2013). Fostering resilience: A necessary skill for teacher retention. Journal of Science Teacher Education, 24, 645-664. https://doi.org/10.1007/s10972-012-9324-x.

Gray, L., \& Taie, S. (2015). Public school teacher attrition and mobility in the first five years: Results from the first through fifth waves of the 2007-08 Beginning Teacher Longitudinal Study. U.S. Department of Education. Washington, DC: National Center for Education Statistics.

Gonzales, L., Brown, M. S., \& Slate, J. (2008). Teachers who left the teaching profession: A qualitative understanding. The Qualitative Report, 13(1), 1-11.

Goldring, R., Taie, S., \& Riddles, M. (2014). Teacher Attrition and Mobility Survey (NCES 2014077). U.S. Department of Education. Washington, DC: National Center for Education Statistics.

Gu, Q., \& Day, C. (2007). Teachers resilience: A necessary condition for effectiveness. Teaching and Teacher Education, 23, 1302-1316. https://doi.org/10.1016/j.tate.2006.06.006.

Gu, Q., \& Day, C. (2013). Challenges to teacher resilience: Conditions count. British Educational Research Journal, 39(1), 22-44. https://doi.org/10.1080/01411926.2011.623152.

Hanushek, E., Kaine, J., \& Rivkin, S. (2004). Why public schools lose teachers. The Journal of Human Resources, 39(2), 326-354.

Herbert, K., \& Ramsay, M. (2004, September). Teacher turnover and shortages of qualified teachers in Texas public school districts 2001-2004. Report to the Senate Education Committee. Retrieved from http://www.sbec.state.tx.us/SBECOnline/reprtdatarsrch/ReportforSenateEducat ionCommittee.pdf.

Howard, S., \& Johnson, B. (2004). Resilient teachers: Resisting stress and burnout. Social Psychology of Education, 7(4), 399-420. 
Johnson, B., Down, B., LeCornu, R., Peters, J., Sullivan, A., Pearce, J., et al. (2014). Promoting early career teacher resilience: A framework for understanding and acting. Teachers and Teaching, 20(5), 530-546. https://doi.org/10.1080/13540602.2014.937957.

Ingersoll, R. (2012). Beginning teacher induction: What the data tell us. Phi Delta Kappan, 93(8), 47-51.

Ingersoll, R., \& Kralik, J. (2004). The impact of mentoring on teacher retention: What the research says. Denver, CO: Education Commission of the States. Retrieved from http://www.gse.upenn. edu/pdf/rmi/ECS-RMI-2004.pdf.

Ingersoll, R., \& Merrill, L. (2012). Retaining teachers: How preparation matters. Educational Leadership, 68(8), 30-34.

Ingersoll, R., \& Strong, M. (2011). The impact of induction and mentoring programs for beginning teachers: A critical review of the research. Review of Educational Research, 81(2).

Kang, S., \& Berliner, D. (2012). Characteristics of teacher induction programs and turnover rates of beginning teachers. The Teacher Educator, 47, 268-282. https://doi.org/10.1080/08878730. 2012.707758 .

Mansfield, C. F., Beltman, S., Broadley, T., \& Weatherby-Fell, N. (2016). BRiTE: Building Resilience in Teacher Education. Australia: Department of Education and Training.

Mansfield, C. F., Beltman, S., Price, A., \& McConney, A. (2012). "Don't sweat the small stuff:" Understanding teacher resilience at the chalkface. Teaching and Teacher Education, 28, 357-367. https://doi.org/10.1016/j.tate.2011.11.001.

Mayer, D., Decker, P., Glazerman, S., \& Silva, T. (2003). Identifying alternative certification programs for an impact evaluation of teacher preparation. U.S. Department of Education. Washington, DC: Mathematica Policy Research.

Peters, J., \& LeCornu, R. (2007). Successful early career teaching: More than engaging pedagogy. Refereed paper presented at the 2006 Australian Association for Research in Education Conference, Adelaide. CD-ISSN 1324-9339.

Public Schools First. (2019). The facts on rural schools. Retrieved from https://www.publicschool sfirstnc.org/resources/fact-sheets/the-facts-on-rural-schools/.

Richards, K. A., Levesque-Bristol, C., Templin, T. T., \& Graber, K. C. (2016). The impact of resilience on role stressors and burnout in elementary and secondary teachers. Social Psychology of Education, 19(30), 511-536. https://doi.org/10.1007/s11218-016-9346-x.

Ronfeldt, M., \& McQueen, K. (2017). Does new teacher induction really improve retention? Journal of Teacher Education, 68(4), 394-410. https://doi.org/10.1177/0022487117702583.

Smith, T., \& Ingersoll, M. (2004). Reducing teacher turnover: What are the components of effective induction? American Educational Research Journal, 41, 681-714.

Tait, M. (2005). Resilience and new teacher success. Education Today, 17(3), 12-13, 41.

Tait, M. (2008). Resilience as a contributor to novice teacher success, commitment, and retention. Teacher Education Quarterly, 35(4), 57-75.

von der Embse, N., Pendergast, L., Segool, N., Saeki, E., \& Ryan, S. (2016). The influence of testbased accountability policies on school climate and teacher stress across four states. Teaching and Teacher Education, 59, 492-502. https://doi.org/10.1016/j.tate.2016.07.013.

Waddel, J. (2007). The time is now: The role of professional learning communities in strengthening the resiliency of teachers in urban schools. In D. Davis (Ed.), Resiliency reconsidered (pp. 123137). Charlotte, NC: Information Age Publishing. 
Open Access This chapter is licensed under the terms of the Creative Commons Attribution 4.0 International License (http://creativecommons.org/licenses/by/4.0/), which permits use, sharing, adaptation, distribution and reproduction in any medium or format, as long as you give appropriate credit to the original author(s) and the source, provide a link to the Creative Commons license and indicate if changes were made.

The images or other third party material in this chapter are included in the chapter's Creative Commons license, unless indicated otherwise in a credit line to the material. If material is not included in the chapter's Creative Commons license and your intended use is not permitted by statutory regulation or exceeds the permitted use, you will need to obtain permission directly from the copyright holder.

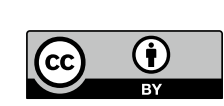

